\title{
OPTIMIZATION OF EDM PROCESS PARAMETERS USING TAGUCHI METHOD: A REVIEW
}

\author{
Harmanpreet $^{1}$, Manpreet Singh $^{2}$, Bipendeep ${ }^{3}$ \\ ${ }^{1}$ M.Tech student, Production Engineering, RIET, Phagwara, India \\ ${ }^{2}$ Asst. Prof., MED, CTPC, Shahpur, Jalandhar, India \\ ${ }^{3}$ M.Tech student, Production Engineering, RIET, Phagwara, India
}

\begin{abstract}
Electrical discharge machining is assessed on the basis of Material Removal Rate (MRR), Tool Wear Rate (TWR), and Surface Roughness (SR). Process parameters that mostly affected the EDM Process are Pulse on Time, Pulse off Time, Discharge Current, Arc Gap and Duty Cycle. This paper reviews research for the optimization and improvement of various performance parameters measured in the experimentation on EDM by using Taguchi technique. In the study the main objectives of optimization is to minimize the tool wear rate (TWR) and surface roughness, and to maximize the material removal rate (MRR).Taguchi Method is widely used in the industry to optimize and improve various performance parameters associated with different machining processes. This paper also deals with the review of some of the work reported with the use of Taguchi method in last two decades.
\end{abstract}

Keywords: - EDM, Wire EDM, MRR, RWR, TWR, SR, Taguchi Technique, $* * *$

\section{INTRODUCTION}

A properly planned and executed experiment is of the utmost importance for originating clear and accurate conclusions from the experimental observations. Design of experiment is considered to be a very useful strategy for accomplishing these tasks. The science of statistical experimental design originated with the work of Sir Ronald Fisher in England in 1920s. Fisher founded the basic principle of investigational design and the associated dataanalysis technique called Analysis of Variance (ANOVA) during his efforts to improve the yield of agricultural crops. The theory and applications of experimental design and the related technique of response surface methodology have been advanced by many statistical researchers as Box and Hunter, Box and Draper, Hicks. Various types of matrices are used for planning experiments to study several decision variables. Among them, Taguchi's Method makes heavy use of orthogonal-arrays. Dr. Taguchi of Nippon Telephones and Telegraph Company, Japan industrialized a method based on "orthogonal-array" experimentations which gives much concentrated "variance" for the experiment with "optimum settings" of control parameters. Thus the manage of DOE with optimization of control parameters to obtain BEST results was achieved in the Taguchi Method. "Orthogonal Arrays" (OA) provide a set of well balanced (minimum) experiments and Dr. Taguchi's Signal-to-Noise ratios $(\mathrm{S} / \mathrm{N})$, which are log functions of desired output, serve as objective functions for optimization, help in data analysis and expectation of optimum results. Now a days Taguchi's methodology is widely used methods all over the globe for research resolutions, specifically to optimise the machining characteristics. In this paper an attempt has been made to put together some of the work done with Taguchi's Methodology. [1]

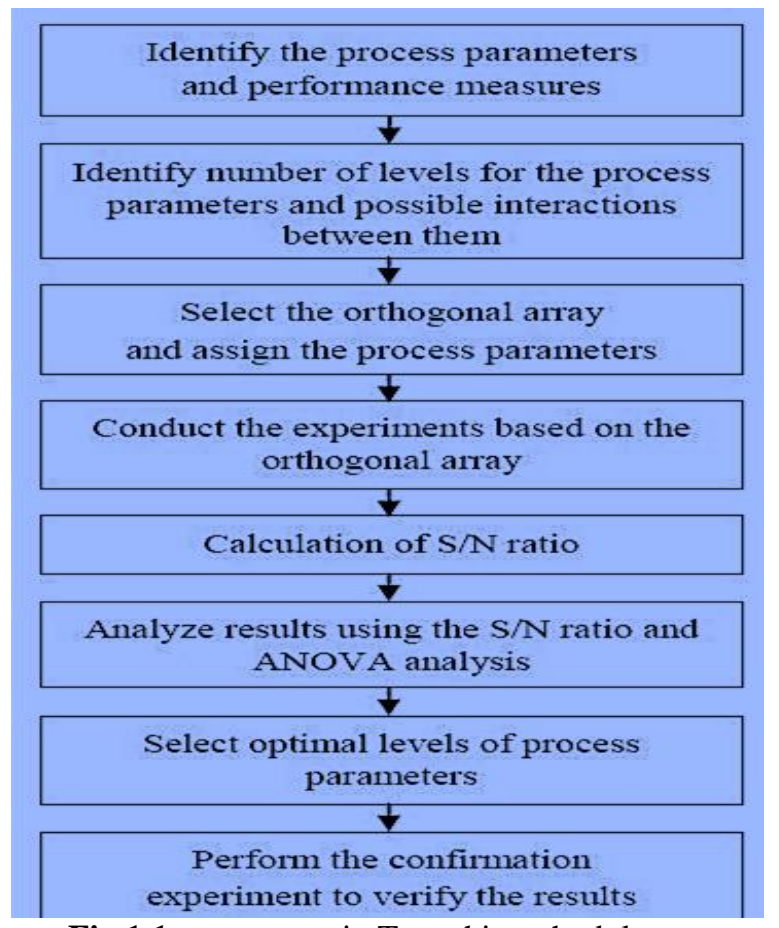

Fig 1.1:- processes in Taguchi methodology

\section{LITERATURE REVIEW}

Y.S Liao in 1997 premeditated on the machining-parameters optimization of wire electrical discharge machining. An approach to determine the parameters were performed. The design was based upon the taguchi quality approach with analysis of the variances (ANOVA). In the research the significant factors affects the machining performance factors such as Material removal rate (MRR), gap width, surface roughness (SR), sparking frequency, average gap voltage 
and normal ratio. In the investigation results demonstrate that the machining models were appropriate and the machining parameters mollify the real requirements [2]. In 2001 Kuo-Ming Tsai, Pei-Jen Wang studied the dimensional analysis for surface finish in electrical discharge machine process. The process parameter for the model were peak current, pulse duration, electrical polarity and property of the materials. They analysed and verified the result by taguchi method. For the experimentation $\mathrm{Cu}, \mathrm{Gr}$ (ISEM-8), Ag-w were used for electrode and AISI EK 2, AISI D2, AISI H13 were used as the work piece material. In the investigation the methodically analyse and verification was performed by taguchi method. In the result it was determined that the predictions for the semi empirical model for the best fitting parameters were obtained by nonlinear optimization methods detected as the good verification experiment [3]. In 2001 investigation was observed by PeiJen Wang, Kuo-Ming Tsai on electrical discharge machine. Peak current, pulse duration, electrical polarity were as performance procedure parameters. The response parameter considered were material removal rate and tool wear rate .In experimentation copper, Gr (ISEM-8) and Ag-w were used as electrode material and EK -2,AISI D2,AISI H13 as work piece material . To optimize standard taguchi method was used and dimensional analysis was considered to analyse the process data. In the experimentation it was perceived that the model of coefficient and power index were established. It was determined that the model was able to give reliable predictions for new process parameters [4]. Puertas and Luis in 2003 studied on the machining parameters of electrical discharge machining. The modelling of the $\mathrm{Ra}$ and $\mathrm{Rq}$ parameters in function of current, pulse time and pause time were arranged. Factorial design of experiments were united with techniques of regression for the modelling behaviour of the functions which was also reliant on the different types of the variables. It was observed that a strong collaborations between the current and the pulse time due to increase in feed rate of current it was observed that surface roughness be contingent for the better arc constancy causing a uniform production of sparks. Author resolved that in the range of $0.5-6 \mathrm{~A}$ there was a great deal of difference in the process duration. So, therefore it make essential to perform a satisfactory selection of the process with a lower process time [5]. In 2004 George, Raghunath, Manocha and Ashish warrier deliberate on carbon-carbon composites over electrical discharge machine (E.D.M). The control parameters used in research were pulse current, gap voltage and pulse-on-time. Where Electrode wear rate (EWR), material removal rate (MRR) were perceived as the response parameters .Experimental design was formed and analysis was accomplished by taguchi approach. It was studied that if the parameters were at lower value, low electrode wear rate was attained and on the other hand material removal rate was achieved at higher rate. In this experimentation L8 orthogonal array was used for Taguchi method. Taguchi method was used for finding the optimum situation for control parameter. Machining parameter were set at their optimum level to mend the process parameters. For this conformation supplementary experiment work was performed on the machine. In this observation they also linked the actual and predicted value of material removal rate (M.M.R), and electrode wear rate (EWR) [6]. In 2005 Kun Ling worked on the electrical discharge machining for the surface finish as the machining process parameter. Aluminium powder was mixed in the dielectric fluid for improving the surface finish. Taguchi L18 method was used for experimentation design. They deliberated control parameters as polarity, peak current, pulse duration, open voltage, gap voltage, and surfactant concentration. For the response parameter surface roughness was measured. In the investigation the authors spotted that when the pure aluminium powder added in the dielectric fluid it does not give better results for the response variables. On the other hand aluminium powder and surfactant both are added it gives better surface finish. By the addition of this mixture lower the insulation property of fluid and also increase the surface status. The major effect of powder is uniform distribution discharge energy in the procedure [7]. Lin Y in 2006 investigated on the Machining characteristics and optimization of SKH57 high speed steel by Taguchi method. With the process parameters as polarity, peak current, auxiliary current with high voltage, pulse duration, servo reference. Material removal rate (MRR), tool wear rate (TWR) and surface roughness were as response mutable. Material removal rate and surface roughness were considered as main parameters. As in the result it was determined that material removal rate (MRR), Tool wear rate (TWR) and surface roughness get increased with appreciated to the peak current [8]. Kansal, Sehijpal Singh \& P. Kumar performed on the Performance parameters of powder mixed electrical discharge machining (PMEDM) through Taguchi methods \& utility concept in 2006. Peak current, pulse duration, duty cycle and powder concentration were as process parameters. Material removal rate, surface roughness and tool wear rate were measured as output variables. In the result it was decided that the concentration of added silicon powder in dielectric fluid and peak current were the most impact parameters for tool wear rate (TWR), material removal rate (MRR) and surface roughness (SR) [9]. Yih-Fong and Fu-Chen in 2007 studied the Multiobjective optimization of high-speed EDM process using a Taguchi fuzzy-based. They studied the optimization of electric discharge machining parameter by the use of SKD11 as work piece and copper as an electrode. The fuzzy logic analysis with taguchi method was considered in experimentation. In the study Fuzzy logic was used for developing the relationship between the machining exactness. The process parameters used in experiment were open circuit voltage, pulse duration, duty cycle, peak current, power concentration regular distance for electrode lift. They use surface finish as response parameter in the experimentation it was concluded that the effect on the accuracy and precision of machining processes were mainly affected by pulse time, duty cycle,peak value of discharge current .Other parameter powder size, powder concentration were affected at low level [10]. Kansal, Sehijpal Singh \& P. Kumar studied the Effect of silicon powder mixed EDM on machining rate of AISI D2 Die steel in 2007. The process parameters were peak current, pulse-off-time, pulse on time, Gap-voltage, Gain, nozzle, flushing-pressure, powder 
concentrations. For the response variable material removal rate (MRR) was considered during the experimentation. It was detected that with powder mixing in the dielectric fluid the response variable get fluctuate from normal performance. In the result it was concluded that powder mixing into the dielectric fluid in electrical discharge machining (EDM) process achieved the better MRR. With this a good surface finish was accomplished in the experimentation [11]. Ei-Taweel, T. A. in 2009 investigated on the Multi-response optimization of EDM with Al-Cu-Si$\mathrm{MiC}$ P/M Composite Electrode. The author investigated the relationship between the process parameters in EDM of CK45 steel with novel tool electrode material by using powder technique. For input process variables peak current, dielectric flushing pressure and pulse on time were considered. TWR and MWR were as response variables. It was concluded that the peak current was found very important factor for both MRR and TWR. Where dielectric flushing pressure was considered less for getting response variables [12]. In 2009, Yen-Cherng Lin described on optimization of machining parameter in magnetic force assisted E.D.M. The Taguchi method with L18 level was used for design of experiment (DOE). Analysis of variance (ANOVA) was observed to analyse the experimental data. The author consider machine polarity, peak current, pulse duration, high voltage current, no load voltage and servo voltage as a process parameters and surface roughness ,material removal rate as response parameters. The main benefit to consider magnetic force were to evaluate the discharge wave form and form of micrograph studied surface integrity .The observation show that magnetic force helped EDM to higher material removal rate and lower tool wear rate and surface roughness in the experiment .The author explained in the journal about the inventors obtained in magnetic assisted E.D.M was smaller than simple E.D.M machine working on the same sample. The author investigated that peak current mainly affected on surface roughness and material removal rate and machine polarity affected the material removal rate only in assisted electrical discharge machine [13]. In 2009 Mohd Amri studied the implementation of Taguchi method on EDM process of Tungsten Carbide. In the research the tungsten carbide was used as the work piece material and graphite as an electrode material. Peak-current, voltage, pulse-on-time and pulse-offtime were considered as process parameters. MRR, EWR and SR were as response parameters. The taguchi method was implemented to convey the experimental layout. It was concluded that peak current was significantly affects the electrode wear rate and surface finish. Where the pulse duration was observed as main variable for material removal rate [14]. Govindan, and Joshi in 2010 studied the Experimental categorisation of material removal in dry electrical discharge drilling. Discharge-current, gap voltage, pulse off time, gas pressure, electrode speed, radial clearance shield at bottom were considered as process parameters during the experimental consideration. Material removal rate (MRR) and Tool wear rate (TWR) were measured as output parameter or response parameters. It was observed in the experimental conditions that at the low discharge energies, single-discharge in dry electrical discharge machining could give larger MRR and the crater radius as equated to dielectric EDM [15]. Prabhu \& Vinayagam In 2011 investigated on atomic force microscope surface of Inconel-825 material with multi-wallcarbon-Nano tube in electrical discharge machining process .The Taguchi method with L9 orthogonal array was used to optimize the process parameters. The author used pulse voltage, pulse duration, pulse current as control parameters and surface finish, $\mathrm{S} / \mathrm{N}$ ratio as reaction parameters. For the experiment Inconel-825 material used as the work piece. From the observation it was observed that an error of measurements in surface roughness with nanotubes was less than without nanotubes used with dielectric fluid in electrical discharge machining (EDM). From the experiment it was cleared that the specimen sparked without carbon Nano tube more surface cracks and less surface morphology on the hand of specimen using with carbon Nano tube [16]. In 2011 Sivapirakasam, JOSE0-Mathew and Suria Narayanam studied about the aerosol produced from die sinking EDM process. In this paper they worked on influence of process parameters working on environment condition of electrical discharge machine. The taguchi method was used to optimize the process parameter in the working environment. Peak current, flushing pressure, pulse duration, dielectric fluid level above the spark location considered as control parameters. To analysis the metal practical present in working environment air inductively coupled plasma (ICP) used. Mass spectrometry coupled with Gas chromatography used to originate hydrocarbon components which was attached to aerosol. The observation shows pulse duration and peak current were most significant parameters that effects on breathing zone concentration of aerosol [17]. Nipanikar and Ghewade in 2011 studied on the machining of the Electro discharge machining of Inconel material. Pulse on time, peak current, duty cycle, gap voltage were considered as performance parameters. For response variables material removal rate (MRR) and tool wear rate (TWR) were considered. The half taper angle of the through holes and over cut was also deliberated during experimentation. In the result it was also concluded that the peak current significantly affects the material removal rate (MRR) and the radial overcut. Were the pulse on time was experimentally observed that it affects the tool wear rate (TWR) [18]. Nipanikar in 2012 executed optimization on the process parameters of EDM by using taguchi method. AISI D3 was treated as the work piece material. Copper was deliberated as the electrode material. Peak current, gap voltage, duty cycle and pulse on time were considered as the process variables. Material removal rate (MRR), electrode wear rate (EWR) and radial overcut (ROC) were investigated as the reaction variables. The taguchi method was considered to constitute the experimental design and to explore for the analysis of the effect of each parameters on the machining characteristics. In the result it was decided that the peak current was mainly affects the material removal rate (MRR) and electrode wear rate (EWR) but duty cycle had least count on it. So Ton was kept at 75us Ip as 8Amp and voltage as 55Volt. L9 orthogonal matrix experiment was performed for taguchi method [19]. In 2012 Harpreet Singh, and Amandeep Singh worked on Effect of 
pulse-on-time and pulse-off-time on machining of AISI D3 die steel material using copper and brass electrode EDM. The article presents the effect on material removal rate (M.R.R) with dissimilar tool materials. AISI D3 was deliberated as the work piece materials. Where copper and brass was well-thought-out as the tool materials. The control parameters were pulse-on-time \& pulse-off-time. The experiment was performed on electrical discharge machine by using kerosene oil as dielectric fluid. They conclude that Material removal rate (M.R.R) was directly proportional to pulse off time and inversely proportional to pulse off time [20]. Samar Singh and Mukesh Verma have used Taguchi method for parametric optimization of electrical discharge drilling machine for better MRR of material. A proposal of experiments based on $\mathrm{L}_{27}$ was carefully chosen for drilling of material. The work piece material was Al-7075. Pulse-ontime, Pulse-off- time and water-pressure was selected as process parameters \& MRR as the output parameter. ANOVA shows the \%age contribution of process parameters in machining of Al-7075 in EDDM. They have establish that the arrangement of maximum Pulse-on-Time \& minimum Pulse-off-Time gives maximum MRR [21]. Raghuraman, Thiruppati, Pannerselvam and Santosh investigated on the Optimization of E.D.M parameters by using Taguchi method and grey-relational-analysis for mildsteel-IS2026 on electrical discharge machine in 2013. The aim of the investigation was to achieve the optimization condition between pulse on and pulse off time in electrical discharge machining process. For this purpose pulse off time and pulse on time were consider as control parameters. MRR, SR and EWR were considered as the response parameters. Mildsteel grade-2026 was used for as a work piece material. Copper rod was used as electrode material. Design of experiment was done with the help of grey relations analysis and for the optimization taguchi method was implemented. The main motive of investigation was to achieve the combined objectives electrode wear rate (EWR), surface roughness (SR) with lower and higher material removal rate. In the experimentation ideal parameters pulse current $26 \mathrm{~A}$, pulse on time $55 \mu \mathrm{s}$ and pulse off time $5 \mu \mathrm{s}$ were considered [22]. D.C.Chen et. al. have used Taguchi's method to optimise EDM process parameters for machining of A 6061-T6 Aluminium alloy, general applicability of the optimum machining parameter was also investigated by machining a CuZn40 alloy. Experiments were performed to check the effect of four process parameters namely Pulse Current, Pulse on Duration, Duty Cycle, and machining duration on SR. They have used ANOM and ANOVA to find the most substantial parameter for surface roughness \& they compared both materials to check the general applicability of Taguchi method [23].Nikalje used Taguchi method to govern the influence of process parameters on MDN-300steel in die sinking EDM. They have selected discharge current, Pulse on Time \& Pulse off time as process parameters \& MRR, TWR, RWR \& SR as response parameters. Copper was selected as the material of electrode. A plan of experimentations established on $\mathrm{L}_{9}$ was used in the study. Each of the process parameters has three levels. After a systematic execution of experiments they found that all three process parameters plays significant role in EDM operation. They also found that the optimal levels of process parameters were same for SR and TWR, but different for MRR \& RWR. Discharge current was found to be most significant for SR and TWR while for MRR \& RWR it was Pulse on Time [24]. Kumar have used Taguchi's method to adjust the parameters of WEDM. $\mathrm{L}_{27}$ orthogonal array was considered for design of experiments. Time on, Time off, Wire Speed \& Wire Feed were carefully chosen as the process parameters \& MRR and SR were selected as the response parameters. Molybdenum wire of $0.18 \mathrm{~mm}$ diameter was used as electrode to drill holes of 5 $\mathrm{mm}$ in diameter on AL-Sic (20\%) plate of thickness $10 \mathrm{~mm}$. The impact of process parameters on machining of drilled holes was also investigated. The result shows that all the parameters plays significant role for MRR \& SR [25]. MK Rodge have used Taguchi technology for examination of effect of parameters on multiple performance parameters such as Cutting Width, Electrode Wear \& Hardness during WEDM of Inconel 625. Pulse on Time, Pulse off Time, Wire Feed, Upper Flush, Lower Flush \& Wire Tension were used as machining process parameters. Five levels of each process parameter were selected for the investigation. A block of Inconel625 with dimensions 100mm X $30 \mathrm{mmX} 10 \mathrm{~mm}$ was selected as work piece. A brass wire of diameter $0.25 \mathrm{~mm}$ was used as electrode. $\mathrm{L}_{25}$ orthogonal array was used to design the structure experiments. All the experiments were performed on Maxicut-e machine. Results exposed that Pulse on Time turns out to be the most significant parameter in machining Inconel $625 \&$ it also have predominant effect on Kerf Width [26]. Abhishek Gaikwad, Amit Tiwari, Amit Kumar and Dhanajay Singh evalued the Effect of edm parameters in locating maximum MRR and minimum EWR by machining SS316 using copper electrode in 2014. The control factor taken during experiment was current, pulse off time, pulse on time and fluid pressure. Material removal rate (MRR) and tool wear rate (TWR) were taken for response variables. Taguchi technique was applied in it. Which statistically helps in decision making for minimum number of experiments and the error association with it. In the result it shows that current and pulse off time has main factor significant for material removal rate and tool wear rate respectively [27]. Vikas, Apurba Kumar Roy, Kaushik Kumar worked on the material EN-31 on electrical discharge machine in 2014. The input parameter were considered as pulse on time, pulse off time, discharge current and voltage with Surface roughness as reaction parameter. For experiment work copper rode and EN-31 material used for tool and work piece respectively. In the experimentation Arithmetic average of absolute values, Root mean squared value, Skewness, Kurtusi sub response parameters were investigated . The design of experiment was consider by grey taguchi method and analysis was prepared by the ANOVA method. In the experiment square shape copper tool was used for machining. In the result it was perceived that current have larger impact on surface roughness as compared to other process parameters [28]. Vikas, Shashikant, A.K Roy and Kaushik Kumar compared the material removal rate (MRR) of two different materials EN19 and EN-41 on die sinking E.D.M machine in 2014. 
Copper was used as tool material in the experimentation .The input parameter considered were pulse on time, pulse off time, discharge current, and voltage. Whereas response parameter material removal rate (MRR) was considered. In the result it was concluded that discharge current was major impact parameter than consider parameters. They also investigate on the study of the carbon composition for both materials. The Taguchi method was used for obtaining maximization condition of response parameter for both materials [29]. Chandramouli have also used Taguchi's methodology for novelty of the optimal process parameters on RENE80 Nickel super alloy material. The design of experiment was studied on the Basis of $\mathrm{L}_{9}$ orthogonal array on V3525 Precision die sink electric discharge machine with Aluminium as tool electrode. The process and response parameters were Current, Pulse on Time, Pulse off Time and MRR, TWR, SR respectively. Results revealed that MRR decreases initially with increase in Pulse on Time increase with increase in Pulse on Time. TWR increases with increase in Current while SR increases with increase in Current \& Pulse on Time but decrease with increase in Pulse off Time [30]. Lodhi have also used Taguchi method to find the effect of machining parameters on SR. The experiments were performed on a smart ZNC-EDM machine with copper tool of $2 \mathrm{~mm}$ in diameter \& Gap Voltage, Discharge Current $\&$ Pulse on Time as process parameters. CFRP composite was used as work piece material in the study. The results shows that at $\mathrm{V}_{\mathrm{g}}=50 \mathrm{~V}, \mathrm{~T}_{\text {on }}=70 \mu \mathrm{s} \& \mathrm{I}_{\mathrm{p}}=2 \mathrm{~A}$, the surface roughness found to be maximum [31]. Selvakumar have also used Taguchi method to elevate WEDM of 5083Aluminium Alloy. The experimentations were performed on an Electra Super Cut-734 series 2000 CNC Wire Cut Machine. Pulse on Time, Pulse off Time, Peak Current \& Wire Tension, was selected as input parameters \& Cutting Speed, SR as response parameters. $\mathrm{L}_{9} \mathrm{OA}$ was used for design of experiments. From analysis of ANOVA they found that CS was independent of Wire Tension \& SR was independent of Pulse off Time \& Wire Tension [32]. Manpreet Singh have used Taguchi $\mathrm{L}_{9} \mathrm{OA}$ to investigate the effect of different wire electrodes on MRR of MS work piece using WEDM process. Material of Wire, Current,
Pulse on Time were selected as input parameters \& MRR as reaction parameter. The experiments were performed on Electronica Sprint Cut WEDM Machine with three different wire electrodes of $0.25 \mathrm{~mm}$ diameter. The material of wire electrode selected was copper, Brass, Zinc coated Brass. From ANOVA analysis they have found that the MRR was more when work piece was machined with Copper electrode and minimum when machined with zinc coated brass at current 3A \& Pulse on Time $130 \mu$ s [33]. ZA Khan also used Taguchi methodology along with grey-relation analysis to investigate the effect of WEDM process parameters on SR average\& Kerf Width of stainless steel (SS-304). The experiments were performed on a Steer Corporation DK7712NC WEDM Machine. Three input parameters namely Current, Pulse on Time, Pulse off Time were selected at levels. Experiments were designed on the basis of $\mathrm{L}_{9}$ OA \& optimisation was done with the help of grey relation analysis. From the experiment they have found that increase in Pulse on Time leads to increase in both SR \& Kerf Width and vice versa. SR was also increased as Pulse Current was increased [34]. BK Lodhi have used Taguchi technique for optimisation of machining parameters in WEDM of AISI D3 Steel. Pulse on Time, Pulse off Time, Peak Current \& Wire Feed was selected as process parameters and SR was reaction parameter. The experiments were conducted on an Electronica Super Cut734 WEDM machine. Zinc coated Brass wire of diameter $0.25 \mathrm{~mm}$ was used as an electrode. The design of experiments was on the basis of $\mathrm{L}_{9} \mathrm{OA}$. Result shows that Pulse on Time \& Current have more effect on SR than other parameters [35]. Radhika have used Taguchi methodology for optimisation of EDM parameters of Aluminium hybrid composites. Process parameters particular for the experimentation were Peak Current, Flushing Pressure, Pulse on Time, whereas MRR, SR \& TWR were selected as response parameters. DOE was based on $\mathrm{L}_{27} \mathrm{OA}$. The experiments were accomplished on Electronica ZNC Small Die Sinker Machine. From results they have found that the Peak Current was the most significant factor for SR, Flushing pressure was found to be most significant factor for MRR \& Pulse on Time was most significant factor for TWR [36].

Table: - 2.1 Optimization of EDM Process Parameters by Taguchi Method

\begin{tabular}{|c|c|c|c|c|c|c|}
\hline Year & Author & Contribution & $\begin{array}{l}\text { Work } \\
\text { piece } \\
\text { material }\end{array}$ & $\begin{array}{l}\text { Electrod } \\
\text { e } \\
\text { material }\end{array}$ & $\begin{array}{l}\text { Machining } \\
\text { Parameters }\end{array}$ & $\begin{array}{l}\text { Performance } \\
\text { parameters }\end{array}$ \\
\hline 1997 & $\begin{array}{l}\text { Liao, Huang, } \\
\text { H.C. Su }\end{array}$ & $\begin{array}{l}\text { study on the machining } \\
\text { parameters } \\
\text { optimization }\end{array}$ & $\begin{array}{l}\text { SKD11 } \\
\text { alloy } \\
\text { steel }\end{array}$ & $\begin{array}{l}\text { Brass } \\
\text { wire }\end{array}$ & $\begin{array}{l}\text { Gap-width, sparking- } \\
\text { frequency, gap-voltage } \\
\text { and normal ratio. }\end{array}$ & MRR, SR \\
\hline 2001 & $\begin{array}{lr}\text { Kuo- } & \text { Ming } \\
\text { Tsai , } & \text { Pei-Jen } \\
\text { Wang } & \end{array}$ & $\begin{array}{l}\text { Semi-empirical model } \\
\text { of surface finish }\end{array}$ & $\begin{array}{l}\text { AISI EK- } \\
2, \mathrm{AISI} \\
\text { D2, AISI } \\
\mathrm{H} 13\end{array}$ & $\begin{array}{l}\text { Gr } \\
\text { (ISEM- } \\
8 \text { ) and } \\
\mathrm{Ag-w}\end{array}$ & $\begin{array}{l}\text { Peak-current ,pulse- } \\
\text { duration, electrical- } \\
\text { polarity and property } \\
\text { of } \\
\text { the materials }\end{array}$ & Surface finish \\
\hline 2001 & $\begin{array}{ll}\text { Pei-Jen } & \text { Wang } \\
\text {,Kuo- } & \text { Ming } \\
\text { Tsai } & \end{array}$ & $\begin{array}{l}\text { Semi-empirical model } \\
\text { on work removal and } \\
\text { tool wear }\end{array}$ & $\begin{array}{l}\text { EK } \quad- \\
\text { 2,AISI } \\
\text { D2,AISI } \\
\text { H13 }\end{array}$ & $\begin{array}{l}\text { Gr } \\
\text { (ISEM- } \\
8 \text { ) and } \\
\text { Ag-w }\end{array}$ & $\begin{array}{l}\text { Peak-current, pulse- } \\
\text { duration ,electrical- } \\
\text { polarity, properties of } \\
\text { material }\end{array}$ & $\begin{array}{l}\text { work removal, } \\
\text { tool wear }\end{array}$ \\
\hline
\end{tabular}




\begin{tabular}{|c|c|c|c|c|c|c|}
\hline 2003 & $\begin{array}{l}\text { I. Puertas and } \\
\text { Luis }\end{array}$ & $\begin{array}{l}\text { Investigated the } \\
\text { machining parameters } \\
\text { and optimization }\end{array}$ & $\begin{array}{l}\text { Steel }(F- \\
1110)\end{array}$ & Copper & $\begin{array}{l}\text { Current-intensity, } \\
\text { pulse-on-time, pulse- } \\
\text { off-time. }\end{array}$ & $\begin{array}{l}\text { Dimensional } \\
\text { precision, Surface } \\
\text { quality. }\end{array}$ \\
\hline 2004 & $\begin{array}{l}\text { George, } \\
\text { Raghunath, } \\
\text { Manocha, } \\
\text { Ashish, } \\
\text { Warrier }\end{array}$ & $\begin{array}{l}\text { EDM machining of } \\
\text { carbon- } \\
\text { composite }\end{array}$ & $\begin{array}{l}\text { Carbon- } \\
\text { carbon } \\
\text { composit } \\
\text { e }\end{array}$ & Copper & $\begin{array}{l}\text { Pulse-on-Time, Pulse- } \\
\text { current, Gap-voltage }\end{array}$ & MRR, TWR \\
\hline 2005 & $\begin{array}{l}\text { Kun Ling Wu, } \\
\text { Biing } \\
\text { HwaYan,Fuan } \\
\text { g Yuan } \\
\text { Husang, Shin } \\
\text { Chang Chin }\end{array}$ & 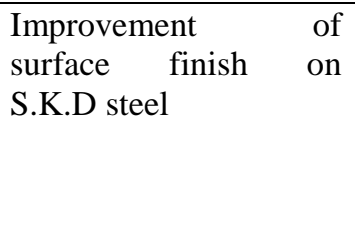 & $\begin{array}{l}\text { SKD-61 } \\
\text { steel }\end{array}$ & $\begin{array}{l}\text { Copper } \\
\text { Tool }\end{array}$ & $\begin{array}{l}\text { polarity, peak current, } \\
\text { pulse duration, open } \\
\text { voltage, gap voltage, } \\
\text { and surfactant } \\
\text { concentration }\end{array}$ & Surface finish \\
\hline 2006 & $\begin{array}{l}\text { Lin, Cheng, su } \\
\text { B.L, \& Hwang }\end{array}$ & $\begin{array}{l}\text { Machining } \\
\text { characteristics and } \\
\text { optimization }\end{array}$ & $\begin{array}{l}\text { SKH57 } \\
\text { high } \\
\text { speed } \\
\text { steel }\end{array}$ & Copper & $\begin{array}{l}\text { polarity, peak-current, } \\
\text { auxiliary current with } \\
\text { high voltage, pulse } \\
\text { duration, } \\
\text { reference }\end{array}$ & $\begin{array}{l}\text { MRR, EWR and } \\
\text { SR }\end{array}$ \\
\hline 2006 & $\begin{array}{l}\text { Kansal, } \\
\text { sehijpal singh } \\
\& \text { P. Kumar }\end{array}$ & $\begin{array}{l}\text { Performance } \\
\text { parameters } \\
\text { optimization } \\
\text { PMEDM }\end{array}$ & ------- & ------- & $\begin{array}{l}\text { Peak-current, pulse- } \\
\text { duration, duty-cycle } \\
\text { and powder- } \\
\text { concentration }\end{array}$ & $\begin{array}{l}\text { MRR, EWR and } \\
\text { SR }\end{array}$ \\
\hline 2007 & $\begin{array}{l}\text { Yih- } \\
\text { Fong.Tzeng,F } \\
\text { u-Chen Chen }\end{array}$ & $\begin{array}{l}\text { Multi-objective } \\
\text { optimization }\end{array}$ & SKD11 & $\begin{array}{l}\text { Copper } \\
\text { Tool }\end{array}$ & $\begin{array}{l}\text { Open-circuit-voltage, } \\
\text { pulse-duration, duty- } \\
\text { cycle, peak current, } \\
\text { power concentration } \\
\text { regular distance for } \\
\text { electrode }\end{array}$ & surface finish \\
\hline 2007 & $\begin{array}{l}\text { Kansal, } \\
\text { Sehijpal singh } \\
\text { \& P. Kumar }\end{array}$ & $\begin{array}{l}\text { Effect of silicon } \\
\text { powder mixed }\end{array}$ & $\begin{array}{l}\text { AISI D2 } \\
\text { Die steel }\end{array}$ & Copper & $\begin{array}{l}\text { peak current, pulse off } \\
\text { tome, pulse on time, } \\
\text { Gap voltage, Gain, } \\
\text { nozzle, flushing } \\
\text { pressure, powder } \\
\text { concentrations }\end{array}$ & MRR \\
\hline 2008 & $\begin{array}{l}\text { Ei-Taweel, T. } \\
\text { A. }\end{array}$ & $\begin{array}{l}\text { Multi-response } \\
\text { optimization }\end{array}$ & $\begin{array}{lll}\text { C } & \text { K } & 45 \\
\text { Steel }\end{array}$ & $\begin{array}{l}\text { Al-Cu- } \\
\text { Si-TiC } \\
\text { P/M } \\
\text { Composi } \\
\text { te }\end{array}$ & $\begin{array}{lr}\text { Peak } & \text { current, } \\
\text { dielectric } & \text { flushing } \\
\text { pressure, pulse on time }\end{array}$ & MRR, TWR \\
\hline 2009 & \begin{tabular}{l}
\multicolumn{3}{l}{ Yen-Cherng } \\
Lin, Yuan- \\
feng Chen \\
,Der-An wang \\
,Ho-Shiun lee
\end{tabular} & $\begin{array}{l}\text { Optimization of } \\
\text { machining parameters }\end{array}$ & SKD-61 & $\begin{array}{l}\text { electrolyt } \\
\text { e copper }\end{array}$ & $\begin{array}{l}\text { machine polarity, peak } \\
\text { current, pulse duration } \\
\text {,high voltage current } \\
\text {,no load voltage and } \\
\text { servo voltage }\end{array}$ & MRR, SR \\
\hline 2009 & $\begin{array}{l}\text { Mohd Amri } \\
\text { Lajis,H.C.D. } \\
\text { Mohd Radzi, } \\
\text { A.K.M. Nurul } \\
\text { Amin }\end{array}$ & $\begin{array}{l}\text { the implementation of } \\
\text { Taguchi method on } \\
\text { EDM }\end{array}$ & $\begin{array}{l}\text { Tungsten } \\
\text { Carbide }\end{array}$ & Graphite & $\begin{array}{l}\text { Peak current, voltage, } \\
\text { pulse on time and } \\
\text { pulse off time }\end{array}$ & $\begin{array}{l}\text { MRR, EWR and } \\
\text { SR }\end{array}$ \\
\hline 2010 & $\begin{array}{l}\text { Govindan, } \\
\text { Joshi }\end{array}$ & $\begin{array}{l}\text { Experimental } \\
\text { description of material } \\
\text { removal in DEDM }\end{array}$ & ------- & --------- & $\begin{array}{l}\text { Discharge current, gap } \\
\text { voltage, pulse off } \\
\text { time, gas pressure, } \\
\text { electrode speed, radial } \\
\text { clearance shield }\end{array}$ & MRR, TWR \\
\hline
\end{tabular}




\begin{tabular}{|c|c|c|c|c|c|c|}
\hline 2011 & $\begin{array}{l}\text { S.PRABHU, } \\
\text { B.K.VINAYA } \\
\text { GAM }\end{array}$ & $\begin{array}{ll}\text { AFM } & \text { surface } \\
\text { investigation } & \end{array}$ & $\begin{array}{l}\text { Inconel - } \\
825 \text { with } \\
\text { multiwall } \\
\text { carbon } \\
\text { Nano } \\
\end{array}$ & copper & $\begin{array}{l}\text { pulse voltage ,pulse } \\
\text { duration, pulse current }\end{array}$ & $\begin{array}{l}\text { surface finish }, \mathrm{S} / \mathrm{N} \\
\text { ratio }\end{array}$ \\
\hline 2011 & $\begin{array}{l}\text { S.Psivapirakas } \\
\text { am,JOSE } \\
\text { Mathew,M.Su } \\
\text { ria narayanam }\end{array}$ & $\begin{array}{l}\text { Constituent Analysis of } \\
\text { aerosol generated }\end{array}$ & $\begin{array}{l}\text { High } \\
\text { carbon } \\
\text { high } \\
\text { chromiu } \\
\text { m tool } \\
\text { steel }\end{array}$ & $\begin{array}{l}\text { Copper } \\
\text { rode }\end{array}$ & $\begin{array}{l}\text { Peak current ,flushing } \\
\text { pressure, pulse } \\
\text { duration, dielectric } \\
\text { fluid level above the } \\
\text { spark location }\end{array}$ & $\begin{array}{l}\text { Analysis of aerosol } \\
\text { generated }\end{array}$ \\
\hline 2011 & $\begin{array}{l}\text { Nipanikar, } \\
\text { Ghewade }\end{array}$ & $\begin{array}{ll}\text { Electro } & \text { discharge } \\
\text { machining } & \end{array}$ & Inconel & Copper & $\begin{array}{l}\text { Pulse on time, peak } \\
\text { current, duty cycle, } \\
\text { gap voltage }\end{array}$ & MRR, TWR \\
\hline 2012 & S.R Nipanikar, & parameter optimization & AISI D3 & copper & $\begin{array}{l}\text { Peak current gap } \\
\text { voltage, duty cycle, } \\
\text { pulse on time. }\end{array}$ & $\begin{array}{l}\text { MRR, TWR, radial } \\
\text { over cut(ROC) }\end{array}$ \\
\hline 2012 & $\begin{array}{l}\text { Harpreet } \\
\text { singh, and } \\
\text { Amandeep } \\
\text { singh }\end{array}$ & $\begin{array}{l}\text { Effect of pulse on/pulse } \\
\text { off time }\end{array}$ & $\begin{array}{l}\text { AISI D3 } \\
\text { die steel }\end{array}$ & $\begin{array}{l}\text { copper } \\
\text { and brass }\end{array}$ & $\begin{array}{l}\text { pulse on, pulse off } \\
\text { time }\end{array}$ & $\begin{array}{l}\text { Material removal } \\
\text { rate }\end{array}$ \\
\hline 2013 & $\begin{array}{l}\text { Raghuraman , } \\
\text { Thiruppati } \\
\text {,Pannerselvam } \\
\text {, santosh }\end{array}$ & $\begin{array}{l}\text { taguchi method and } \\
\text { gray relational analysis }\end{array}$ & $\begin{array}{l}\text { Mild } \\
\text { steel } \\
\text { IS2026 }\end{array}$ & $\begin{array}{l}\text { Copper } \\
\text { tool }\end{array}$ & $\begin{array}{l}\text { Pulse off time and } \\
\text { pulse on time }\end{array}$ & MRR, TWR,SR \\
\hline 2013 & $\begin{array}{l}\text { Chen, Jhang, } \\
\text { Guo }\end{array}$ & $\begin{array}{l}\text { Application of Taguchi } \\
\text { Design }\end{array}$ & $\begin{array}{l}\text { A6061- } \\
\text { T6 } \\
\text { Aluminu } \\
\text { m Alloy }\end{array}$ & Copper & $\begin{array}{l}\text { Pulse on Duration, } \\
\text { Pulse current, Duty } \\
\text { Cycle }\end{array}$ & SR \\
\hline 2013 & $\begin{array}{lr}\text { Nikalje, } & \text { A. } \\
\text { Kumar, } & \text { Sai } \\
\text { Srinadh } & \end{array}$ & $\begin{array}{l}\text { Parameter } \quad \& \\
\text { Optimization }\end{array}$ & $\begin{array}{l}\text { MDN } \\
300 \text { Steel }\end{array}$ & Copper & $\begin{array}{l}\text { Pulse on time, pulse } \\
\text { off time, Discharge } \\
\text { Current }\end{array}$ & MRR, TWR, RWR \\
\hline 2013 & $\begin{array}{l}\text { K.Kumar, R. } \\
\text { Ravikumar }\end{array}$ & $\begin{array}{ll}\text { Modeling } & \text { and } \\
\text { Optimization } & \end{array}$ & $\begin{array}{l}\text { Al-Sic } \\
(20 \%)\end{array}$ & $\begin{array}{l}\text { Molybde } \\
\text { num wire }\end{array}$ & $\begin{array}{l}\text { Pulse on time, pulse } \\
\text { off time, Wire Speed, } \\
\text { Wire Feed }\end{array}$ & MRR, SR \\
\hline 2013 & $\begin{array}{l}\text { MK Rodge, } \\
\text { SS Sarpate, } \\
\text { SB Sharma }\end{array}$ & $\begin{array}{l}\text { Process Response and } \\
\text { Parameters WEDM }\end{array}$ & $\begin{array}{l}\text { Inconel } \\
625\end{array}$ & $\begin{array}{l}\text { Brass } \\
\text { Wire }\end{array}$ & $\begin{array}{l}\text { Pulse on time, pulse } \\
\text { off time, Wire Feed, } \\
\text { Upper Flush Lower } \\
\text { Flush, Wire Tension }\end{array}$ & MRR, Kerf Width \\
\hline 2013 & $\begin{array}{l}\text { Raghurama, } \\
\text { Thiruppati,pan } \\
\text { nerselvam,San } \\
\text { tosh }\end{array}$ & $\begin{array}{l}\text { taguchi method and } \\
\text { grey relational analysis }\end{array}$ & $\begin{array}{ll}\text { mild } & \\
\text { steel } & \text { IS } \\
2026 & \end{array}$ & $\begin{array}{l}\text { copper } \\
\text { tool }\end{array}$ & $\begin{array}{l}\text { pulse off time and } \\
\text { pulse on time }\end{array}$ & $\begin{array}{l}\text { MRR, TWR, and } \\
\text { SR }\end{array}$ \\
\hline 2014 & $\begin{array}{l}\text { Abhishek } \\
\text { gaikwad, Amit } \\
\text { tiwari, Amit } \\
\text { Kumar, } \\
\text { Dhanajay } \\
\text { Singh }\end{array}$ & $\begin{array}{l}\text { obtaining maximum } \\
\text { MRR and minimum } \\
\text { EWR }\end{array}$ & $\begin{array}{l}\text { SS316 } \\
\text { Steel }\end{array}$ & Copper & $\begin{array}{l}\text { current, pulse off time, } \\
\text { pulse on time and fluid } \\
\text { pressure }\end{array}$ & MRR, TWR \\
\hline 2014 & \begin{tabular}{lr}
\multicolumn{2}{l|}{ Vikas ,Apurba } \\
kumar roy, \\
Kaushik & \\
Kumar &
\end{tabular} & $\begin{array}{l}\text { Effect and optimization } \\
\text { of various machine } \\
\text { process parameters }\end{array}$ & EN-31 & copper & $\begin{array}{l}\text { pulse on time, pulse } \\
\text { off time, discharge } \\
\text { current and voltage }\end{array}$ & $\begin{array}{l}\text { arithmetic average } \\
\text { of absolute values } \\
\text { root mean squared } \\
\text { value ,skewness } \\
\text {,kurtusis }\end{array}$ \\
\hline
\end{tabular}




\begin{tabular}{|c|c|c|c|c|c|c|}
\hline 2014 & $\begin{array}{l}\text { Vikas } \\
\text {,Shashikant } \\
\text {,AK roy, } \\
\text { Kaushik }\end{array}$ & $\begin{array}{l}\text { optimization } \quad \text { of } \\
\text { machine } \\
\text { parameter }\end{array}$ & $\begin{array}{ll}\text { EN } & -19 \\
\text { and } & \mathrm{EN}- \\
41 & \end{array}$ & copper & $\begin{array}{l}\text { pulse on time, pulse } \\
\text { off time, discharge } \\
\text { current and voltage }\end{array}$ & $\begin{array}{l}\text { Material removal } \\
\text { rate }\end{array}$ \\
\hline 2014 & $\begin{array}{l}\text { Chandramouli, } \\
\text { Balraj } \\
\text { Shrinivas, } \\
\text { Eswaraiah }\end{array}$ & $\begin{array}{l}\text { Optimization of EDM } \\
\text { Process Parameters }\end{array}$ & $\begin{array}{l}\text { RENE } 80 \\
\text { Nickel } \\
\text { Super } \\
\text { Alloy }\end{array}$ & $\begin{array}{l}\text { Aluminu } \\
\mathrm{m}\end{array}$ & $\begin{array}{l}\text { Pulse on time, pulse } \\
\text { off time, Current }\end{array}$ & MRR, TWR, SR \\
\hline 2014 & $\begin{array}{l}\text { Brajesh } \\
\text { Kumar Lodhi, } \\
\text { Deepak } \\
\text { Verma, Rahul } \\
\text { Shukla }\end{array}$ & $\begin{array}{l}\text { Optimization of } \\
\text { Machining Parameters } \\
\text { in EDM }\end{array}$ & $\begin{array}{l}\text { CFRP } \\
\text { Composi } \\
\text { te }\end{array}$ & Copper & $\begin{array}{l}\text { Gap voltage, discharge } \\
\text { current, Pulse on time }\end{array}$ & SR \\
\hline 2014 & $\begin{array}{l}\text { Selvakumar, } \\
\text { Sornalatha, } \\
\text { Sarkar, Mitra }\end{array}$ & $\begin{array}{l}\text { Investigation and Multi } \\
\text { Objective Optimization }\end{array}$ & $\begin{array}{l}5083 \\
\text { Aluminu } \\
\text { m Alloy }\end{array}$ & $\begin{array}{l}\text { Copper } \\
\text { Wire }\end{array}$ & $\begin{array}{l}\text { Pulse on time, pulse } \\
\text { off time, Wire } \\
\text { Tension, peak current }\end{array}$ & Cutting Speed, SR \\
\hline 2014 & $\begin{array}{l}\text { Manpreet } \\
\text { singh, } \\
\text { Amandeep } \\
\text { Singh Bansal, } \\
\text { Sanjeev } \\
\text { Kumar }\end{array}$ & $\begin{array}{l}\text { Effect of Different } \\
\text { Wire Electrodes }\end{array}$ & $\begin{array}{l}\text { Mild } \\
\text { Steel }\end{array}$ & $\begin{array}{l}\text { Copper } \\
\text { Wire, } \\
\text { Brass } \\
\text { Wire, } \\
\text { Zinc } \\
\text { coated } \\
\text { Brass } \\
\text { Wire }\end{array}$ & $\begin{array}{l}\text { Material of wire, } \\
\text { Current, Pulse on time }\end{array}$ & MRR \\
\hline 2014 & $\begin{array}{l}\text { Zahid Khan, } \\
\text { Arshad } \\
\text { Siddiquee, } \\
\text { Noor Zaman } \\
\text { Khan, Urfi } \\
\text { Khan, Quadir }\end{array}$ & $\begin{array}{lr}\text { Multi } & \text { Response } \\
\text { Optimization } & \text { of } \\
\text { WEDM } & \end{array}$ & $\begin{array}{l}\text { Stainless } \\
\text { Steel } \\
(\mathrm{SS}-304)\end{array}$ & $\begin{array}{l}\text { Copper } \\
\text { Wire }\end{array}$ & $\begin{array}{l}\text { Pulse on time, pulse } \\
\text { off time, Current }\end{array}$ & SR, Kerf Width \\
\hline 2014 & $\begin{array}{l}\text { Brajesh } \\
\text { Kumar Lodhi, } \\
\text { Sanjay } \\
\text { Agarwal }\end{array}$ & \begin{tabular}{l}
\multicolumn{2}{l}{ Optimization of } \\
Machining Parameters \\
in WEDM
\end{tabular} & $\begin{array}{ll}\text { AISI D3 } \\
\text { Steel }\end{array}$ & $\begin{array}{l}\text { Zinc } \\
\text { coated } \\
\text { Brass } \\
\text { Wire }\end{array}$ & $\begin{array}{l}\text { Pulse on time, pulse } \\
\text { off time, Peak Current, } \\
\text { Wire Feed }\end{array}$ & SR \\
\hline 2014 & $\begin{array}{l}\text { N.Radhika, } \\
\text { Sudhamshu, } \\
\text { Kishore } \\
\text { Chandran }\end{array}$ & $\begin{array}{l}\text { Optimization of EDM } \\
\text { Parameters }\end{array}$ & $\begin{array}{l}\text { Aluminu } \\
\text { m Hybrid } \\
\text { Composi } \\
\text { tes }\end{array}$ & Copper & $\begin{array}{lr}\text { Pulse on time, Peak } \\
\text { Current, } \\
\text { Pressure }\end{array}$ & MRR, SR,TWR \\
\hline
\end{tabular}

\section{CONCLUSION}

From the literature review it can be concluded that the Taguchi Method is widely used and most effective technique for the optimization of machining parameters. Review also reveals that machining by EDM and WEDM is generally assessed on the basis of MRR, TWR \& SR. Paper also revealed that Pulse on Time, Pulse off Time, Duty Cycle, Dielectric Flushing Pressure, Peak Current, Cycle Voltage are some of the factors that affects the machining characteristics of EDM process.

\section{REFERENCES}

[1] Manpreet Singh, "To Study the Effect of Cryogenic Treatment on Wire Electrodes of WEDM Process" Thesis Report, PTU Jalandhar, 2014.

[2] Y.S. Liao, J.T. Huang, H.C. Su, "A study on the machining-parameters optimization of wire electrical discharge machining", Journal of Materials Processing Technology, pp.487-493, 1997.

[3] Kuo- Ming Tsai, Pei-Jen Wang' “Semi-empirical model of surface finish on electrical discharge machining", internal journal of machine tools \& manufacture, pp1455-1477, 2001. 
[4] Pei-Jen Wang, Kuo- Ming Tsai, "Semi-empirical model on work removal and tool wear in electrical discharge machining", Journal of Materials Processing Technology, pp.117, 2001.

[5] I. Puertas, C.J. Luis, "A study on the machining parameters of electrical discharge machining", Journal of Materials Processing Technology, pp.521526, 2003.

[6] P.M. George, B.K. Raghunath, L.M. Manocha, Ashish M.Warrier, " EDM machining of carboncarbon composite- a Taguchi approach", journal of Material processing Technology, pp.66-71, 2004.

[7] Kun Ling Wu, Biing Hwa Yan, Fuang Yuan Husang, Shin Chang Chin, "Improvement of surface finish on S.K.D steel using electro-discharge machining with aluminium and surfactant added dielectric", International journal of machine tools \& Manufacture, pp.1195-1201, 2005.

[8] Lin y. c., Cheng C. H., Su B. L., Hwang L. R., "Machining characteristics and optimization of SKH57 high speed steel using electrical discharge machining based on Taguchi method", Material \& Manufacturing process, 21:8, pp.922-929, 2006.

[9] Kansal, Sehijpal Singh, P. Kumar, "Performance parameters optimization (multi characteristics) of powder mixed electrical discharge machining (PMEDM) through Taguchi methods \& utility concept", Indian journal of Engineering \& materials science, 13(3), pp.209-216, 2006.

[10] Yih-Fong.Tzeng, Fu-Chen Chen, "Multi-objective optimization of high-speed electrical discharge machining process using a taguchi fuzzy-based approach", Materials and design, pp.1159-1168, 2007.

[11] Kansal, Sehijpal singh, P. Kumar, " Effect of silicon powder mixed EDM on machining rate of AISI D2 Die steel", Journal of Manufacturing process, 9(1), pp.13-22, 2007.

[12] Ei-Taweel, T. A., "Multi-response optimization of EDM with Al-Cu-Si-MiC P/M Composite Electrode", International Journal of Advance Manufacturing Technology, pp.100-113, 2009.

[13] Yen-Cherng Lin, Yuan-feng Chen, Der-An wang,HoShiun lee, "Optimization of machining parameters in magnetic force assisted E.D.M based on Taguchi method", Journal of materials processing Technology, pp.3374-3383, 2009.

[14] Mohd. Amri Lajis, H.C.D. Mohd Radzi, A.K.M. Nurul Amin, "The Implementation of Taguchi Method on EDM Process of Tungsten Carbide", European Journal of Scientific research, vol26, issue no.4, pp.609-616, 2009.

[15] Govindan, P.; Joshi, S.S., "Experimental characterization of material removal in dry electrical discharge drilling", International journal of machine tools and manufacturing, 50(5), pp.431-443, 2010.

[16] S.PRABHU, B.K.VINAYAGAM, "AFM surface investigation of Inconel 825 with multiwall carbon nano tube in electrical discharge machining process using Taguchi analysis", Archives of civil and mechanical engineering, pp.149-170, 2011.

[17] S.Psivapirakasam, JOSE Mathew, M.Suria narayanam, "Constituent Analysis of aerosol generated from die sinking electrical discharge machining process", Process safety and environment protection, pp.141-150, 2011.

[18] Nipanikar, S.R.; Ghewade, D.V., "Electro discharge machining of Inconel material", International journal of engineering research and technology, 4(2), pp.157169, 2011.

[19] S.R.Nipanikar, "parameter optimization of electro discharge machining of AISI D3 steel material by using taguchi method", Journal of Engineering Research and Studies, ISSN0976-7916, Vol. 3, issue 3, pp.7-10, 2012.

[20] Harpreet Singh, and Amandeep Singh , "Effect of pulse on/pulse off time on machining of AISI D3 die steel using copper and brass electrode in E.D.M", International journal of engineering and science ISSN:2278-4721, vol.1, issue 9, pp19-22, 2012.

[21] Samar Singh, Mukesh Verma, "A Parametric Optimization of Electric Discharge Drill Machine Using Taguchi Approach", Journal of Engineering, Computers \& Applied Sciences, Vol. 1, No. 3, pp.3944, 2012.

[22] Raghuraman S, Thiruppati K pannerselvam T. Santosh, " Optimization of E.D.M parameters using Taguchi Method and Grey Relational Analysis for Mild Steel IS 2026", International journal of innovative research in science engineering and technology, ISSN:2319-8753,vol.2,issue 7, pp.30953104, 2013.

[23] D.C. Chen, J.J. Jhang, M.W. Guo, “ Application of Taguchi Design Method to Optimize the Electrical Discharge Machining" JAMME, Vol. 57, Issue 2, pp. 76-82, 2013.

[24] A.M. Nikalje, A. Kumar, K.V. Sai Srinadh, "Influence of Parameter \& Optimization of EDM Performance Measures on MDN 300 Steel Using Taguchi Method", IJAMT, 2013.

[25] K. Kumar, R. Ravikumar, "Modeling and Optimization of Wire EDM Process" IJMER, Vol. 3, Issue. 3, pp. 1645-1648, 2013.

[26] M.K. Rodge, S.S. Sarpate, S.B. Sharma, "Investigation on Process Response and Parameters in Wire Electrical Discharge Machining of Inconel 625", IJMET, Vol.4, Issue. 4, pp. 54-65, 2013.

[27] Abhishek Gaikwad, Amit Tiwari, Amit Kumar, Dhanajay Singh, "Effect of edm parameters in obtaining maximum Mrr and minimum EWR by machining SS316 using copper electrode", IJMET, Vol.5, Issue 6, pp.102-110, 2014.

[28] Vikas, Apurba Kumar Roy, Kaushik Kumar", "Effect and optimization of various machine process parameters on the surface roughness in E.D.M for on EN-31 material using grey taguchi”, procedia materials science, pp.383-390, 2014. 
[29] Vikas, Shashikant, A.k roy, Kaushik kumar, "Effect and optimization of machine process parameter son MRR for EN -19 and EN -41 using taguchi”, procedia materials science, pp.204-210, 2014.

[30] S. Chandramouli, Balraj U. Shrinivas, K. Eswaraiah, "Optimization of Electrical Discharge Machining Process Parameters Using Taguchi Method”, IJAME, Vol.4, No.4, pp. 425-434, 2014.

[31] Brajesh Kumar Lodhi, Deepak Verma, Rahul Shukla, "Optimization of Machining Parameters in EDM of CFRP Composite Using Taguchi Technique", IJMET, Vol.5, Issue.10, pp.70-77, 2014.

[32] G. Selvakumar, G. Sornalatha, S. Sarkar, S. Mitra, "Experimental Investigation and Multi Objective Optimization of Wire Electrical Discharge Machining of 5083 Aluminum Alloy", Transactions of Nonferrous Metals Society of China 24, pp.373379, 2014.

[33] Manpreet Singh, Amandeep Singh Bansal, Sanjeev Kumar, "The Effect of Different Wire Electrodes on the MRR of MS Workpiece Using WEDM Process", IJMET, Vol.5, Issue.5, pp.180-188, 2014.

[34] Zahid A. Khan, Arshad N. Siddiquee, Noor Zaman Khan, Urfi Khan, G.A. Quadir, "Multi Response Optimization of Wire Electrical Discharge Machining Process Parameters Using Taguchi Based Grey Relation Analysis", $3^{\text {rd }}$ ICMPC, pp.1683-1695, 2014.

[35] Brajesh Kumar Lodhi, Sanjay Agarwal, "Optimization of Machining Parameters in WEDM of AISI D3 Steel Using Taguchi Technique", $6^{\text {th }}$ CIRP International Conference on High Performance Cutting, pp.194-199, 2014.

[36] N.Radhika, A.R. Sudhamshu, G. Kishore Chandran, "Optimization of Electrical Discharge Machining Parameters of Aluminium Hybrid Composites Using Taguchi Method", Journal of Engineering Science and Technology, Vol.9, No.4, pp. 502-512, 2014.

\section{BIOGRAPHIES}

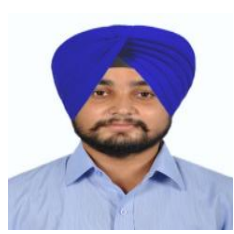

Harmanpreet received his B.Tech degree in Mechanical Engineering from DAV Institute of Engineering and Technology, Punjab Technical University, Jalandhar, India in 2012. M.Tech degree in Production Engineering from Ramgarhia Institute of Engineering and Technology, Phagwara, India from Punjab Technical University in 2015.

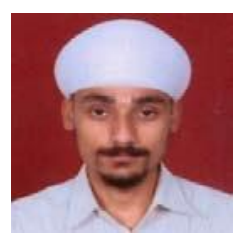

Manpreet Singh received his B.Tech. Degree, in Mechanical Engineering \& M.Tech. Degree, in Production Engineering from Ramgarhia Institute of Engineering \& Technology, Phagwara, India, in 2008 and 2014 respectively. He is having 1 year industrial experience and 2 years teaching experience as well.

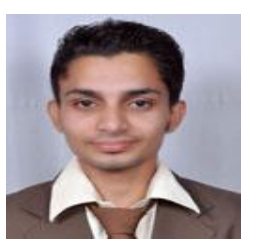

Bipendeep received his B.Tech degree in mechanical engineering from Chandigarh engineering college landran, Mohali, India in 2013. M.Tech degree in Production Engineering from Ramgarhia Institute of Engineering and Technology, Phagwara, India from Punjab Technical University in 2015. 